ZałącZnIil

\title{
LOKOMOTYWA NA NOWYCH TORACH, CZYLI JAK UWSPÓŁCZEŚNIA SIĘ TUWIMA
}

\author{
MONIKA JANUSZ-LORKOWSKA
}

\begin{abstract}
Wydział Dziennikarstwa Informacji i Bibliologii UW Faculty of Journalism Information and Book Studies, University of Warsaw m.janusz-lorko@uw.edu.pl
\end{abstract}

Twórczość Juliana Tuwima to ogromne pole dla odkrywczej adaptacji, intersemiotycznych przekładów i intertekstualnych nawiązań, czasem niezwykle luźno powiązanych $\mathrm{z}$ oryginałem. Fakt ten wynika nie tylko z geniuszu poety i nowatorskich możliwości, jakie daje jego spuścizna, ale również z innych, dość przyziemnych przyczyn. Jedną z nich jest problem z pozyskaniem prawa do wykorzystania utworu: prawami dysponuje Fundacja im. Juliana Tuwima i Ireny Tuwim i zdarza się, że instytucja ta stawia surowe warunki licencyjne.

Gdy Sejm RP ustanowił rok 2013 Rokiem Juliana Tuwima, w wyniku czego pojawiły się rozmaite granty, a także potrzeby wydawnicze i wystawiennicze związane z twórczością poety, wielu twórców, napotykając na trudności z pozyskaniem praw autorskich lub w celu uniknięcia kosztów z tym związanych, zaproponowało kompilacje artystyczne z wykorzystaniem jedynie fragmentów utworów Tuwima, opierając się na tak zwanym prawie cytatu („dozwolony użytek publiczny”, art. 29 ust. 1 pr. aut. $\left.{ }^{1}\right)$. Niektórzy wykazali się jeszcze większą kreatywnością, proponując

1 Ustawa $\mathrm{z}$ dnia 4 lutego $1994 \mathrm{r}$. o prawie autorskim i prawach pokrewnych; rozdz. 3 art. 29 pr. aut.: „Wolno przytaczać w utworach stanowiących samoistną całość urywki rozpowszechnionych utworów oraz rozpowszechnione utwory plastyczne, utwory fotograficzne lub drobne utwory w całości, w zakresie uzasadnionym celami cytatu, takimi jak wyjaśnianie, polemika, analiza krytyczna i naukowa, nauczanie lub prawami gatunku twórczości"; http://prawo.sejm.gov. pl/isap.nsf/DocDetails.xsp?id=WDU19940240083 [dostęp: 30.07.2019]. 
utwory, które nie bazowały nawet na cytacie, ale na skojarzeniu, rytmie, powszechnej znajomości wierszy Tuwima. Poprzez luźne powiązanie, dialog z twórczością i życiem poety, stworzyli zupełnie nową jakość, wywołując inne niż zazwyczaj zaangażowanie odbiorcy / widza / czytelnika.

W artykule zostaną przypomniane niektóre tego typu realizacje, a szerzej omówione zostaną trzy wyjątkowo nietypowe kreacje na podstawie / w nawiązaniu do słynnej Lokomotywy Tuwima: spektakl Wędrownego Teatru Lalek MAŁE MI, wystawa plenerowa Fundacji Kultury Dwukropek oraz książka typu picturebook autorstwa artystek Małgorzaty Gurowskiej i Joanny Ruszczyk. Przypomniana zostanie też historia i podstawowe interpretacje utworu Lokomotywa oraz podjęta będzie próba krótkiego wyjaśnienia instytucji prawa cytatu.

\section{ROK 2013 ROKIEM TUWIMA}

7 grudnia 2012 roku Sejm Rzeczypospolitej Polskiej VII kadencji przyjął uchwałę w sprawie ustanowienia roku 2013 Rokiem Juliana Tuwima. Zdecydowana większość - 426 posłów - głosowała „Za”.

W 2013 roku przypadają sześćdziesiąta rocznica śmierci i stulecie poetyckiego debiutu Juliana Tuwima. Obie rocznice stanowią okazję do oddania hołdu temu wielkiemu Poecie, który kształtował język, wyobraźnię i społeczną wrażliwość wielu pokoleń Polaków, ucząc ich zarazem poczucia humoru i ukazując optymizm codziennego życia. Julian Tuwim to wybitny pisarz, autor wierszy dla dorosłych i dzieci, słów piosenek, tekstów dla kabaretów, rewii, operetek, ale także redaktor i tłumacz poezji obcojęzycznej. Współzałożyciel grupy poetyckiej „Skamander” i stały współpracownik „Wiadomości Literackich”, jeden z najpopularniejszych poetów dwudziestolecia międzywojennego, którego twórczość wpłynęła na następne pokolenia $[\ldots]$.

- tak uzasadniał swoją decyzję Sejm w nowo przyjętej uchwale. 19 grudnia rozporządzenie opublikowano w „Monitorze Polskim”2. Tym samym rok 2013 jako Rok Juliana Tuwima stał się faktem.

2 „Monitor Polski” 2012, poz. 988; http://prawo.sejm.gov.pl/isap.nsf/ DocDetails.xsp?id=WMP20120000988 [dostęp: 25.07.2019]. 
Wszelkie okrągłe rocznice związane z uznanymi artystami i ich twórczością są, co do zasady, doskonałym pretekstem, by wznawiać ich utwory, analizować je na nowo, a życie samych artystów wspominać i wyjaśniać w historycznym kontekście. Oficjalne ogłoszenie fetowania czyjejś twórczości, w dodatku fetowania całorocznego, implikuje też tak istotną kwestię, jak uruchomienie publicznych środków finansowych na to przeznaczonych. Również w roku 2013 Minister Kultury i Dziedzictwa Narodowego RP przeznaczył na ten cel specjalną pulę. W związku z Rokiem Juliana Tuwima upoważniony przez ministra Polski Instytut Książki przeprowadził konkurs „projektów promujących myśl i twórczość poety w kraju i za granicą”3. Jego

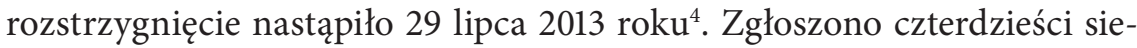
dem projektów, z czego wybrano dwadzieścia, i na podstawie kosztorysów przedstawionych w ofertach wsparto je kwotą 755 tys. zł. Wśród oferentów i zwycięzców konkursu znalazły się takie podmioty jak Biblioteka Sląska, Centrum Myśli Jana Pawła II, Instytucja Promocji i Upowszechniania Muzyki „Silesia”, Uniwersytet Łódzki, Teatr Pinokio, Nadbałtyckie Centrum Kultury, Fundacja Czas Dzieci, Fundacja Sztuczna. Większość z inicjatyw miała charakter sceniczno-happeningowy, temporalny. Wśród tych, z którymi możemy obcować do dziś, są przede wszystkim książki: Tuwim. Wiersze dla dzieci w różnorodnym opracowaniu graficznym Anny Niemierki, Marty Ignerskiej, Małgorzaty Gurowskiej, Agnieszki Kucharskiej-Zajkowskiej, Moniki Hanulak, Justyny Wróblewskiej i Małgorzaty Urbańskiej-Macias, wydana przez wielokrotnie nagradzaną za swoje przedsięwzięcia Wytwórnię, oraz Lokomotywa/IDEOLO, która ukazała się nakładem Fundacji Sztuczna w opracowaniu Joanny Ruszczyk i Małgorzaty Gurowskiej, a inspirowana była słynną Tuwimowską Lokomotywą.

Fundusze na wydarzenia związane z Rokiem Tuwimowskim przekazywały różne instytucje. Za granicą np. Instytuty Polskie, w kraju - samorządy, organizacje w rodzaju Centrum Dialogu im. Marka Edelmana czy Dom Literatury w Łodzi. Łódź, jako miasto urodzenia i dorastania poety,

3 Ogłoszenie konkursu na stronie internetowej Instytutu Książki: https:// instytutksiazki.pl/aktualnosci,2,rok-tuwima,1713.html [dostęp: 26.07.2019].

${ }_{4}$ Informację o wynikach konkursu można przeczytać w Sprawozdaniu z działalności Instytutu Książki w 2013 roku: http://bip.instytutksiazki.pl/attachments/ article/87/Sprawozdanie_2013.pdf, s. 24-26 [dostęp 26.07.2019]. 
została nieformalną stolicą obchodów. Dziennikarz i publicysta Łukasz Kaczyński opisał wtedy w „Dzienniku Łódzkim” niemal wszystkie miejskie przedsięwzięcia związane $\mathrm{z}$ Rokiem Tuwima. Zadawał przy tym pytania o zasadność i cel niektórych inicjatyw (np. rozstawiania zarówno przy głównej ulicy miasta - Piotrkowskiej, jak i w popularnych centrach handlowych pomalowanych przez studentów posągów Tuwima). Za najlepsze ze wszystkich uznał powstanie Art-Lokomotywy w Manufakturze. „Inicjatywa Stowarzyszenia Łódź Filmowa miała szansę stać się promocyjnym znakiem Roku Tuwima - pisał. - Art-Lokomotywa, czyli zabytkowa kolejka »ubrana« w barwny, tęczowy, kostium autorstwa Agaty »Olek« Oleksiak, mieszkającej w Nowym Jorku mistrzyni włóczkowego street-artu (znanej z »ubrania« m.in. posągu Szarżującego Byka, symbolu Wall Street), wykroczyła poza schematy myślenia o rocznicowym wydarzeniu”.

Zaznaczyć należy, że jedna czwarta dofinansowanych wówczas przez MKiDN projektów odwoływała się, w sposób bezpośredni lub pośredni, do sztandarowego dzieła Tuwima - wiersza Lokomotywa. Gdyby dokładnie prześledzić proces wznawiania, adaptowania, kreatywnego interpretowania, uzupełniania etc. dzieł Tuwima na przestrzeni kilkudziesięciu lat, z dużym prawdopodobieństwem mogłoby się okazać, że utwór Lokomotywa był tym, po który sięgano najczęściej. Niezwykłe ilustracje na podstawie tego wiersza już w latach 30. XX wieku stworzyli Jana Lewitt i Jerzy Him - działający w Londynie duet uznanych polskich malarzy i grafików. Lokomotywę ilustracyjnie interpretowali po II wojnie światowej Olga Siemaszko, Jan Lenica, Jan Marcin Szancer, a na scenie wybitni aktorzy - Daniel Olbrychski, Wojciech Pszoniak, Piotr Fronczewski ${ }^{7}$. Była wystawiana w teatrze (najwięcej dostępnych recenzji dotyczy spektaklu w reżyserii Piotra Cieplaka, który miał swoją premierę w Teatrze Powszechnym w Warszawie 27 lutego 2013),

5 Ł. Kaczyński, Rok Tuwima 2013 w Łodzi, czyli połowa roku gruszek na wierzbie, „Dziennik Łódzki”, 4 stycznia 2014; https://dzienniklodzki.pl/rok-tu wima-2013-w-lodzi-czyli-polowa-roku-gruszek-na-wierzbie/ar/1080788 [dostęp: 30.07.2019].

${ }^{6}$ Ibidem.

7 Spektakl telewizyjny Wiersze, Teatr Telewizji TVP, premiera: 1 czerwca 1979 r., wolny dostęp na platformach: YouTube (https://www.youtube.com/watch?v=NLT_ Yx5yhGo) i CDA (https://www.cda.pl/video/469633a) [dostęp: 30.07.2019]. 
ekranizowana (niezwykła adaptacja filmowa Zbigniewa Rybczyńskiego z 1976 roku zrealizowana przez Studio Małych Form Filmowych „SE-MAFOR"8) i odśpiewywana (np. w 2009 roku przez raperkę Lilu - jej oryginalne i dość kontrowersyjne wykonanie ukazało się na płycie Poeci hip-hopowego zespołu White House, wydanej nakładem wytwórni Warner Music Poland). Jest to tekst popularny, lubiany, co istotne - mocno obecny w zbiorowej świadomości, przez co chętnie się go trawestuje, parafrazuje, polemizuje $\mathrm{z}$ nim poprzez nawiązania intertekstualne. Interesujące są zwłaszcza te artystyczne i twórcze nawiązania do Lokomotywy, które nie interpretują utworu bezpośrednio, niezależnie od wyboru rodzaju intersemiotycznego przekładu', lecz inspirują się nim. Z inspiracji Tuwimowską Lokomotywa powstały parafrazy stworzone przez kilkunastoletnie dzieci: dramatyczne wiersze, świadectwa tragedii Zagłady, jak Bełżec Janki Hescheles, Lokomotywa Jerzego Ogórka, Pociag świst Jerzego Orłowskiego ${ }^{10}$. Po wojnie do tematyki tej, również z inspiracji Lokomotywą, nawiązywali tacy poeci jak Wisława Szymborska (Jeszcze), Tadeusz Różewicz (nożyk profesora), Stanisław Wygocki (Lokomotywa). Przykładem współczesnej parafrazy Tuwimowskiej Lokomotywy jest piosenka Lokomotywa Czesława Mozila, traktująca o polskich emigrantach zarobkowych ${ }^{11}$ oraz wspomniana już Lokomotywa/IDEOLO Małgorzaty Gurowskiej i Joanny Ruszczyk (choć tu

8 Film można zobaczyć m.in. na platformach: YouTube (https://www.youtube. com/watch?v=IgGQYyethAQ) i CDA (https://www.cda.pl/video/5383938d) [dostęp: 5.08.2019]. Informacje o współtwórcach filmu: http://www.filmpolski.pl/fp/index. php?film=428064 [dostęp: 5.08.2019].

9 Zob. S. Balbus, Interdyscyplinarność - intersemiotyczność - komparatystyka, [w:] Intersemiotyczność. Literatura wobec innych sztuk (i odwrotnie), red. S. Balbus, A. Hejmej, J. Niedźwiedź, Kraków [cop. 2004], s. 11-16; E. Szczęsna, Wprowadzenie do poetyki intersemiotycznej, [w:] Intersemiotyczność..., op. cit., s. 29-39.

10 Do wierszy tych dotarł i omówił Arkadiusz Morawiec w referacie Lokomotywa (do Bełżca) Janki Hescheles podczas Międzynarodowej Konferencji Naukowej „Tuwim bez końca”, organizowanej przez Katedrę Literatury Polskiej XX i XXI wieku Uniwersytetu Łódzkiego oraz Muzeum Miasta Łodzi w dniach 5-7 grudnia 2013 r. w Łodzi, w Pałacu Poznańskich, w kooperacji z łódzkim Domem Literatury oraz Centrum Dialogu im. Marka Edelmana.

${ }^{11}$ LP Czesław Śpiewa \& Arte dei Suonat, wyd. Mystic Production, premiera: 3 marca 2017. 
parafraza występuje tylko na poziomie graficznym). Wszystkie te realizacje można ująć pod wspólnym hasłem „Loko-Motyw” - w taki, niezwykle trafny sposób zatytułowała swój projekt Wojewódzka i Miejska Biblioteka Publiczna w Bydgoszczy, przystępując w Roku Tuwimowskim do konkursu o grant w Instytucie Książki ${ }^{12}$.

Z racji niewspółmiernie dużej liczby przykładów twórczości loko-motywowej w stosunku do planowanej objętości artykułu szerzej przytoczone zostaną tu trzy realizacje. Przede wszystkim wzmiankowana już książka Lokomotywa/IDEOLO Małgorzaty Gurowskiej i Joanny Ruszczyk, wystawa „Wagoniki Tuwima” Fundacji Kultury Dwukropek oraz spektakl TUWIM Julek - PARA buch, FRAZY w ruch Wędrownego Teatru Lalek Małe Mi. Uprzednio należy jednak przypomnieć historię pierwowzoru czyli Lokomotywy Juliana Tuwima w jej oryginalnej postaci.

\section{LOKOMOTYWA - HISTORIA I NIEKTÓRE INTERPRETACJE}

Lokomotywa Tuwima po raz pierwszy ukazała się drukiem w kwietniu 1936 roku w „Wiadomościach Literackich”. „Ozdobiona była ilustracją Jadwigi Hładkówny, co badacze uznali za szczególną nobilitację literatury dziecięcej"13. Tuwim był już wówczas twórcą blisko setki wierszy. Dwa lata później Lokomotywa była już na tyle znana, że stała się tytułowym utworem tomiku wydanego w grudniowym okresie przedświątecznym przez warszawską oficynę Jana Przeworskiego, pod zachęcającym do kupienia tytułem Lokomotywa i inne wesołe wierszyki dla dzieci. Od roku 1935 aż do wybuchu wojny Tuwim stworzył większość wierszy, o których mówi się, że są utworami dla dzieci. Dyzio Marzyciel, Słoń Trąbalski, Dwa Michały, O panu Tralalińskim, Słoń Trąbalski, Ptasie radio, W aeroplanie - wszystkie one powstały właśnie w tamtym okresie.

Zbigniew Lisowski w latach 80. XX wieku zanalizował i zinterpretował Lokomotywę Tuwima na potrzeby podręczników pedagogicznych ${ }^{14}$.

12 Sprawozdanie z działalności..., op. cit., s. 25.

13 S. Wysłouch, „Lokomotywa” Tuwima w książe i na ekranie, [w:] Literatura w kregu sztuki. Tematy - konteksty - medialne transformacje, red. B. Przymuszała, S. Wysłouch, Poznań 2016, s. 175.

14 Z. Lisowski, Próba interpretacji „Lokomotywy” Juliana Tuwima, „Zeszyty Naukowe WSR-P im. G. Dymitrowa w Siedlcach” 1988, nr 15, cz. 2, s. 33-43. 
Sześćdziesiąt siedem wersów utworu podzielił na trzy sekwencje - statyczną, intensyfikującą prędkość i dydaktyczną. Pomiędzy sekwencjami wyróżnił łączniki: miniaturową przypowiastkę o tysiącu atletów oraz „pragmatyczne” pytania o tajemnicę napędu maszyny parowej. Zalecał przyszłym nauczycielom zrobienie rejestru zawartości wagonów i sam taki sporządził. Dostrzegał analogię między wagonem z „samymi grubasami z kiełbasami” a wagonem $z$ „samymi tuczonymi świniami”. Zauważył niepokojący dorosłego czytelnika kontrast pomiędzy wagonem $\mathrm{z}$ instrumentami muzycznymi a wagonem $z$ armatą, a także fakt, że poeta nie zdradził zawartości większości brankardów, pozostawiając to wyobraźni odbiorcy. Jako specjalista odkrył oczywiście wszystkie językowe niuanse odpowiedzialne za niezwykłą dynamikę i rytm wiersza, analizując liczne onomatopeje i plastyczne porównania. Za przyczynę sukcesu Lokomotywy wśród dzieci uznał te środki stylistyczne, które wskazują na jej ciężar, siłę i ogrom, przez co pozwalają poczuć się przy niej absolutnie małym i słabym (nawet gdy jest się atletą). Niezwykle ważne jest też jego zdaniem spersonifikowanie maszyny parowej: „Metaforyczne zestawienie motywów potu i oliwy, zwłaszcza zaś zdominantyzowanie pierwszego $\mathrm{z}$ nich i lokalizacja drugiego aż na samym końcu dopowiedzenia (które ponadto tworzy następny już werset), sugerują czytelnikowi możliwość potraktowania »bohaterki« wiersza jako "postaci«. [...] Deskryptor lokomotywy daje mianowicie do zrozumienia, że właśnie pot - jak z żywej istoty - z niej ścieka (choć w rzeczywistości jest to tylko »oliwa«)"15. Co ciekawe, podobnie zinterpretował/zobaczył Lokomotywę reżyser Zbigniew Rybczyński (laureat Oscara w 1981 roku za film Tango), w którego animacji (Lokomotywa, 1977) niemal przez cały czas trwania sześciominutowego filmu oglądamy grubasa w różnych sytuacjach i konfiguracjach, który poci się, jest mu gorąco, wzdycha i sapie ${ }^{16}$. W tle odśpiewywany jest, na wiele głosów - damskich i męskich, tekst wiersza Tuwima.

15 Ibidem, s. 35 .

16 Lokomotywa, reż. Z. Rybczyński, Studio Małych Form Filmowych „SE-MA-FOR”, Łódź 1977; wolny dostęp na platformach: YouTube (https://www.youtube. com/watch?v=IgGQYyethAQ) i CDA (https://www.cda.pl/video/5383938d) [dostęp: 5.08.2019]. Informacje o współtwórcach filmu: http://www.filmpolski.pl/fp/index. php?film=428064 [dostęp: 5.08.2019]. 
Z kolei Dominik Grabowski w tekście Dlaczego? (kwartalnik „Poezja i dziecko") próbuje dociec, czy Tuwima faktycznie wolno nazywać poetą dla dzieci. „Śmiało rzec można, że słabo interesował się literaturą dla najmłodszych - pisze Grabowski - przyglądał się jej, co najwyżej, z boku [...]. Nie sięgał po rolę twórcy dla dzieci, i oto nagle, podobnie jak Brzechwa, objawił wielką znajomość dziecięcej psychiki, a ponadto fenomenalny słuch na dziecięcą zabawę słowem. [...] Dlaczego? Tuwim rozmiłowany w językowej zabawie spostrzegł, iż czyni to także dziecko, że jest ono najdoskonalszym przykładem bezinteresownego bzdurzenia, jest od zawsze twórcą nonsensów"17.

Tego, że Lokomotywa jest wierszem doskonałym, ale jednak dla dorosłych, dowodził też poeta, krytyk i publicysta Jarosław Mikołajewski na łamach „Gazety Wyborczej”: „To wiersz dla ekstremalnie dorosłych, który na szczęście podoba się dzieciom"18. Przekonywał, że dowodem na to jest chociażby miejsce debiutu utworu - łamy „Wiadomości Literackich”, które do pismo adresowane było do wyrobionego, dorosłego czytelnika. Drugim argumentem jest fakt, że wiersz powstał w epoce futurystów i skamandrytów, a Lokomotywa idealnie się wpisuje w ich program i założenia:

Czym był futuryzm, każdy wie. Sztuką (w tym poezją) nowoczesności, zgiełku i miasta, ruchu i szybkości, potencji i potęgi, młodości i antytradycji. Sztuką chwilami śmieszną, chwilami groźną (we Włoszech popierał go Mussolini), niekiedy ciekawą, przejmującą - rzadko. Sprzeczną wewnętrznie, bo nastawioną na tworzenie nowego języka starymi środkami. Paradoksalną wręcz w przypadku Juliana Tuwima, który jako skamandryta z jednej strony konserwował tradycyjne metody wierszowania, $\mathrm{z}$ drugiej - wrzeszczał jak barbarzyńca ${ }^{19}$.

Mikołajewski przypomina też, że w ówczesnym czasie w Europie powstawały podobne do Lokomotywy wiersze, i to z myślą o dorosłych, a nie

17 D. Grabowski Dlaczego?, „Poezja i Dziecko” 2004, nr 4, s. 11-16.

18 J. Mikołajewski, Lokomotywa i inne wesołe wierszyki, Tuwim, Julian, „Gazeta Wyborcza”, 22 listopada 2003; http://wyborcza.pl/1,75517,1786015.html [dostęp: 10.08.2019].

19 Ibidem. 
dziecięcych czytelnikach. Dowodem na to ma być, uznawana za odpowiednik Lokomotywy, Chora fontanna włoskiego futurysty Alda Palazzeschiego ${ }^{20}$.

W naturze poezji leży ponadpokoleniowość - przekonuje Mikołajewski - bo poezja to nie tylko poetyka dorosłego wywodu, który wynika z doświadczenia życia i wiedzy, lecz przede wszystkim język pomiędzy dźwiękiem i sensem. [...] Poezja znaczy nawet w chwili, gdy jej znaczenia są przed nami ukryte ${ }^{21}$.

Seweryna Wysłouch przypomina z kolei o skrajnie różnym interpretowaniu Lokomotywy w roku 1951 przez realistów i formalistów. Ci pierwsi zarzucali autorowi wiersza ignorowanie praw fizyki przy tworzeniu dydaktycznej poezji, drudzy podkreślali wyższość formy nad treścią. Wysłouch przyznała rację tym drugim: „Niezwykły kształt językowy utworu, nazwanego przez Michała Głowińskiego [formalistę - M.J.-L.] arcydziełem, decyduje o jego popularności i zapewnia mu miejsce w kanonie. [...] Dominantą jest bowiem warstwa brzmieniowa: rytm, onomatopeje i echolalie, ona podporządkowuje sens i logikę wypowiedzi"22. Polska literaturoznawczyni mówi też o obecnie „potrójnym życiu” Lokomotywy: 1) w lekturze przeznaczonej do czytania i recytacji, 2) w parafrazach i intertekstualnych nawiązaniach, 3) w przekładach - międzyjęzykowych i intersemiotycznych ${ }^{23}$. Trudno się z tym nie zgodzić.

\section{INTERSEMIOTYCZNE PRZEKŁADY ${ }^{24}$, INTERTEKSTUALNE NAWIĄZANIA}

W roku 2013, Roku Juliana Tuwima, Lokomotywę multiplikowano na niespotykaną wcześniej skalę w każdej z „trzech wersji życia” wyróżnionych wyżej

${ }^{20} \mathrm{~W}$ Polsce w przekładzie Jalu Kurka w tomiku: Chora fontanna. Wiersze futurystów włoskich (Buzzi, Congiullo, Folgore, Govoni, Marinetti, Palazzeschi, Soffici), Kraków 1977.

${ }^{21}$ J. Mikołajewski, op. cit.

22 S. Wysłouch, op. cit., s. 176.

23 Ibidem, s. 177.

24 Wiele różnorodnych naukowych analiz sposobów przekładu intersemiotycznego nie zostanie tu zaprezentowanych z powodu obszerności zagadnienia. Zaznaczyć jednak trzeba, iż można byłoby tu przedstawić koncepcje m.in. Jurija 
przez Sewerynę Wysłouch. W przypadku życia „pierwszego” - i w dużej mierze „trzeciego” - twórczo mogło odbywać się to tylko za zgodą właścicieli majątkowych praw autorskich do utworu, a więc na podstawie licencji (najczęściej odpłatnej). W przypadku życia „drugiego” twórcy często korzystali $\mathrm{z}$ uwzględnionego $\mathrm{w}$ polskim prawie autorskim prawa do cytatu.

Autorskie prawa majątkowe do całej spuścizny Ireny i Juliana Tuwimów posiada przybrana po II wojnie światowej przez parę córka - Ewa TuwimWoźniak, oraz ustanowiona przez nią Fundacja im. Juliana Tuwima i Ireny Tuwim. Instytucja informuje o tym na swojej stronie internetowej ${ }^{25}$. Na wysłane mailem, na potrzeby niniejszego artykułu, zapytanie o liczbę zgłoszeń z prośbą o licencję w związku z rokiem 2013 (Rokiem Tuwima), nie nadeszła z Fundacji żadna odpowiedź. W kwestii ceny za udzielenie praw - zależy ona od wielu czynników (rodzaj utworu, nakład, zakres i czas rozpowszechniania, charakter przedsięwzięcia: komercyjne lub niekomercyjny etc.) i jest ustalana indywidualnie.

W Roku Tuwimowskim i później zaistniały związane z obchodami realizacje, których twórcy nie musieli starać się o licencję u spadkobierców Tuwima. To na przykład plenerowy spektakl Wędrownego Teatr Lalek Małe Mi: TUWIM Julek - PARA buch, FRAZY w ruch, będący doskonałym przykładem na to, jak można mówić o słynnym poecie i jego twórczości, bazując wyłącznie na odwoływaniu się do zbiorowej świadomości, w której słynne utwory Tuwima żyją, są, funkcjonują międzypokoleniowo. Wystarczy, jak w popularnym programie TVP „Jaka to melodia”, usłyszeć jedną nutę utworu lub przypomnieć zaledwie kilka sylab składających się na krótki

Łotmana, Mario Praza, Rolanda Barhes'a, Umberto Eco, Jakuba Lalewicza oraz Mieczysława Porębskiego, przy jednoczesnym zaakcentowaniu, że Lokomotywa Tuwima była przekładana zarówno na rysunek, grafikę ilustracyjną, malarski obraz, jaki i na spektakl, film i dźwięk, a każda z wyszczególnionych materii z jednej strony była uwarunkowana medialnie, $\mathrm{z}$ drugiej - sama implikowała nowy artystyczny przekaz.

25 „Fundacja im. Juliana Tuwima i Ireny Tuwim jest jedynym właścicielem autorskich praw majątkowych do wszystkich utworów Juliana Tuwima i Ireny Tuwim. [...] Twórców utworów słowno-muzycznych, opracowań i adaptacji prosimy o kontakt z Fundacją, by uzyskać zgodę i zarejestrować utwory w ZAiKS-ie"; http://www.tuwim.org/index.php?p=4 [dostęp: 10.08.2019]. 
epizod dzieła, by zgromadzona publiczność je rozpoznała i spontanicznie, zbiorowo odtworzyła. Tak jest też w przypadku Lokomotywy. Powszechna znajomość tego utworu sprawia, że wystarczy użyć jednej frazy występującej w wierszu, np. „para-buch”, by publiczność wiedziała, o którym autorze i o jakim jego utworze mowa. Twórcy spektaklu TUWIM Julek - PARA buch, FRAZY w ruch ${ }^{26}$ wzmacniają dodatkowo tę sugestię wszelkimi dostępnymi dla teatru środkami: dźwiękiem, rytmem, kostiumem, rekwizytami, scenografią. Mimo iż wykorzystywane w ich przedstawieniu wiersze i fragmenty utworów pochodzą najczęściej od innych autorów niż Julian Tuwim (np. Na peronie Pawła Beręsewicza, Wiersz o piwie i lokomotywie Wandy Chotomskiej, Pociąg do muzyki Izabelli Klebańskiej), to wygłaszane są one przez aktorów w specyficznym dla Lokomotywy rytmie, przy wtórze świstów, gwizdów, sapnięć, stukotów. W tym samym czasie zza scenografii bucha para. W takiej aranżacji nikomu z widzów nie przeszkadza, gdy po scenie toczy się, zamiast lokomotywy, słoń. Najważniejsze, że słoń jest ogromny, ciężki i pewnie pot z niego spływa.

Widowisko TUWIM Julek - PARA buch, FRAZY w ruch nie jest ani adaptacją, ani parafrazą, ani nawet przekładem intersemiotycznym ${ }^{27}$. Pozostaje twórczą kreacją, którą można rozważać na poziomie intertekstualnym. Choć w całości poświęcone Julianowi Tuwimowi, to jednak cytaty z utworów poety pojawiają się tu sporadycznie. Twórcy spektaklu, jakkolwiek działają bez porozumienia z Fundacją Ewy Tuwim, mieszczą się w granicach

${ }^{26}$ TUWIM Julek - PARA buch, FRAZY w ruch, Wędrowny Teatr Lalek MAŁE MI, reż. i wyk. S. Tarkowska z udziałem: G. Wielgus/Gracholka Grachola; scenariusz: M. Guśniowska; wsparcie reżyserskie: P. Bikont; scenografia: K. Kalmus, M. Janiak, G. Gorzkiewicz; muzyka: J. „Budyń” Szymkiewicz, A. Orlowski, M. Siłownik; na podstawie książek: A. Frączek, Rany Julek! O tym, jak Julian Tuwim został poetą, Łódź 2013; P. Beręsewicz, M. Brykczyński, W. Chotomska, A. Frączek, I. Klebańska, J. Papuzińska, M. Rusinek, B. Stenka, K. Szymeczko, P. Wakuła, R. Witek, TUWIMOWO, Łódź 2013; spektakl zrealizowany w Muzeum Książki Artystycznej Jadwigi i Pawła Tryzno, dofinansowany ze środków Ministerstwa Kultury i Dziedzictwa Narodowego oraz Urzędu Miasta Łodzi.

27 J. Lalewicz, Mimetyzm formalny i problem naśladowania w komunikacji literackiej, [w:] Tekst i fabuła, red. C. Niedzielski, J. Sławiński, Wrocław 1979, s. 33-47. 

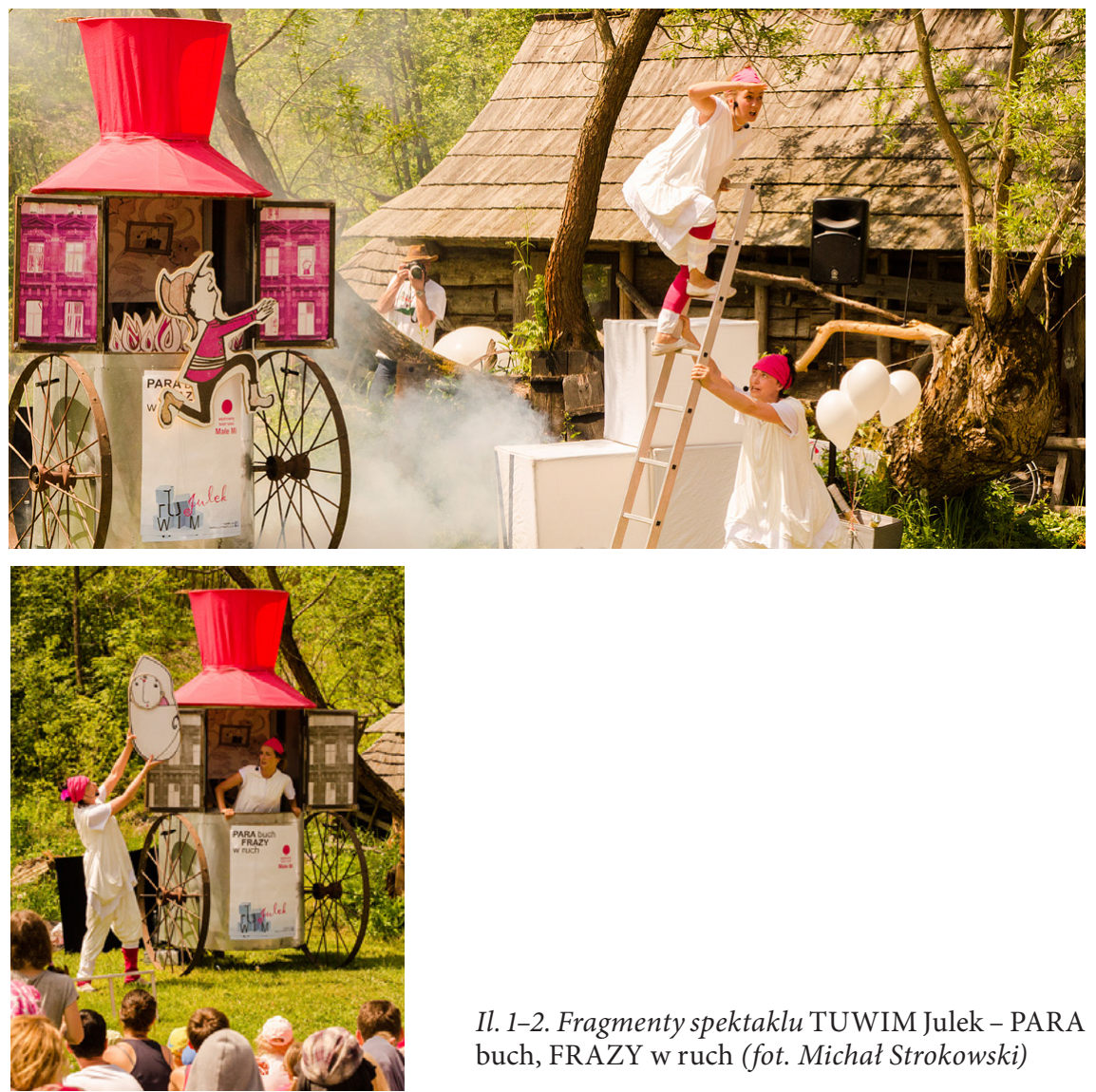

Il. 1-2. Fragmenty spektaklu TUWIM Julek - PARA buch, FRAZY w ruch (fot. Michał Strokowski)

obowiązującego prawa autorskiego mówiącego o ochronie własności intelektualnej (il. 1-2).

Podobnie rzecz ma się z plenerową wystawą Wagoniki Tuwima Fundacji Kultury Dwukropek. Tu twórcy - na banerach reklamowych o kształcie dużych prostokątów (o wymiarach: $1,5 \times 2 \mathrm{~m}$ ), na materiale typu plandeka wydrukowali różne ilustracje do Lokomotywy Tuwima. Każdy prostokąt to jeden wagon, każdy wagon to inny ilustrator. Wystawa ma przypominać, jak wielu świetnych malarzy i grafików obrazowało słynny wiersz oraz jak wiele już było jej książkowych wydań wypuszczanych w obieg przez różnych 
wydawców. I tak na wystawowych banerach znajduje się np. ilustracja Jana Lewitta i Jerzego Hima (grubasy; J. Przeworski 1938), Olgi Siemaszko (armata; Nasza Księgarnia 1954), Katarzyny Boguckiej (krowy; Visart 2013), Małgorzaty Gurowskiej (ludzie; Wytwórnia 2007), Marianny Oklejak (świnie; projekt dla kula.gov.pl 2009), Adama Pękalskiego (żyrafy; Nasza Księgarnia 2012), Daniela de Latour (fortepiany; Egmont 2013), Jana Lenicy (szafy; Polonia 1958) i Agaty Królak (prezenty; Centrum Myśli Jana Pawła II 2013). Całość (czyli tak „zmiksowany” pociąg) „ciągnie” baner, na którym widoczna jest słynna lokomotywa, zwizualizowana przez Jana Marcina Szancera na okładce pierwszego powojennego wydania tomiku Lokomotywa i inne wesołe wierszyki dla dzieci z 1949 roku (Książka i Wiedza). O niemal każdej z tych ilustracji można powiedzieć, że jest intersemiotycznym przekładem znaków werbalnych na wizualne, ale - czy na poziomie znaczeniowo-kulturowym? ${ }^{28}$ Każdy taki przekład to osobista interpretacja wiersza Tuwima, a to skutkuje powstaniem nowego ${ }^{29}$, w tym przypadku - plastycznego utworu. Producent musiał uzyskać zgody do wykorzystania ilustracji na potrzeby stworzenia wystawy, lecz nie od Fundacji Ewy Tuwim, ale od każdego z autorów obrazkowych „wagonów” występujących na ekspozycji (lub od wydawców książek, z których pochodziły ilustracje).W efekcie powstała wystawa, dzięki której ilustratorzy zbiorowo, w sposób pośredni, lecz skuteczny, spopularyzowali polskiego poetę i kolejne wydania jego słynnej Lokomotywy, choć sam tekst wiersza nigdzie na ekspozycji się nie pojawia (il. 3-4).

\section{IDEOLO DLA DOROSEYCH}

Jedną z najciekawszych realizacji powstałych dzięki uruchomieniu specjalnych publicznych funduszy w Roku Tuwimowskim jest książka Lokomotywa/ IDEOLO, wydana nakładem Fundacji Sztuczna, w opracowaniu graficznym Małgorzaty Gurowskiej, opatrzona tekstem skompilowanym przez Joannę Ruszczyk $^{30}$. Jest to książka koncepcyjna, pomyślana jako spójna całość zarówno pod względem treści, strony wizualnej, jak i formy. Dzięki temu

28 Zob. M. Hopfinger, Adaptacje filmowe utworów literackich. Problemy teorii i interpretacji, Wrocław 1974.

29 Zob. A. Helman, Twórcza zdrada. Filmowe adaptacje literatury, Poznań 1998.

30 M. Gurowska, J. Ruszczyk, Lokomotywa/IDEOLO, wyb. J. Ruszczyk, Warszawa 2013. 

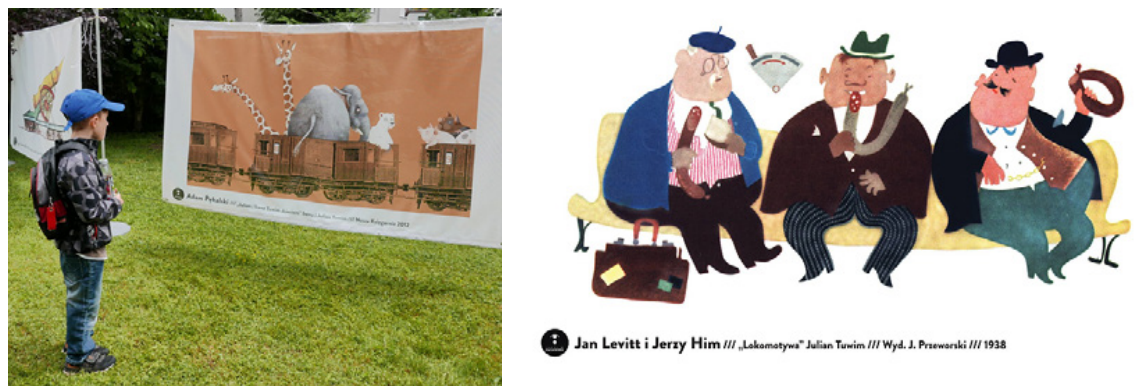

Il. 3-4. Fragmenty wystawy Wagoniki Tuwima Fundacji Kultury Dwukropek

mamy do czynienia $\mathrm{z}$ wartością dodaną w postaci ikonotekstu i interferentnych znaczeń. Już sama jej forma jest nietypowa - graficzka zaproponowała kształt leporello. W takim formacie książka pozostaje kodeksem: ma okładkę, grzbiet, strony, te ostatnie jednak są ze sobą tak połączone, że przy jednoczesnym rozłożeniu przypominają wstęgę, wielokrotnie, równomiernie i naprzemiennie załamywaną do postaci harmonijki (il. 5).

W projekcie Gurowskiej i Ruszczyk każdą stronę wypełnia jedna ilustracja - na pierwszej jest to lokomotywa, na kolejnych i na ostatniej-pojedyncze wagony. Po rozciągnięciu leporello propozycja artystek kojarzy się z pociągiem dużo bardziej niż jakakolwiek inna forma książki. W dodatku z pociągiem bardzo okazałym, ponieważ stron jest tu pięćdziesiąt cztery, a tym samym wagonów więcej niż oryginalnych czterdzieści („a tych wagonów jest ze czterdzieści, sam nie wiem, co się w nich jeszcze mieści”) - po rozłożeniu tworzą wstęgę długą na około szesnaście metrów. A jednak nie jest to książka-zabawka. Najprawdopodobniej nie jest to w ogóle propozycja dla dzieci, mimo że wśród nagród, które otrzymała (m.in. Złoty Medal European Design Awards 2015, nagroda Polskiego Towarzystwa Wydawców Książek - Najpiękniejsza Książka Roku oraz nagroda Polskiej Sekcji IBBY / International Board on Books for Young People - Książka Roku 2014), znajduje się nagroda dla książek dziecięcych. Całość skomponowana została minimalistycznie, bazując na kategorii kontrastu - w kolorach czarnym i białym (w żadnym momencie nie towarzyszy im inna barwa). Ilustracje Gurowskiej nie należą do wesołych. To zwielokrotnione, powtarzalne - niczym pieczątki stawiane bezwiednie przez znudzonego urzędnika - motywy zwierząt, ludzkich postaci, żołnierzy, karabinów, laboratoryjnych probówek, 


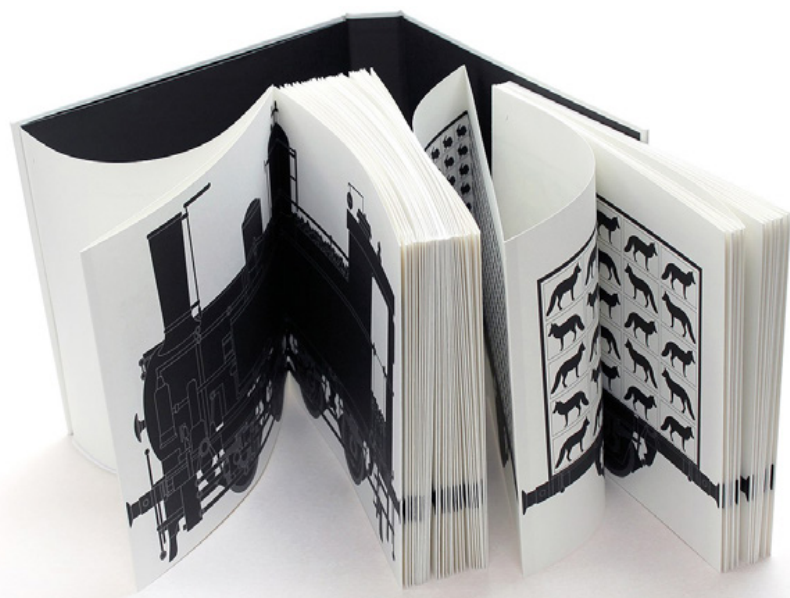

Il. 5. Książka Lokomotywa/IDEOLO, oprac. graficzne M. Gurowska, wyb. J. Ruszczyk, Fundacja Sztuczna, Warszawa 2013

roślin i drzew. Wszystkie schematyczne, stechnicyzowane, „masowe”. Realia nie są uszczegółowione, ludzie nie są zindywidualizowani (il. 6-7). Według niektórych opinii ${ }^{31}$ ilustracje Gurowskiej są „historyzujące” i nawiązują do modernistycznej grafiki dwudziestolecia międzywojennego, prac awangardystów z grupy Blok, którzy zgodnie z hasłem 3M (Miasto, Masa, Maszyna) wprowadzali do ilustracji elementy kanciaste, techniczne; jednak „szablon”, modelowa konturowość, schematyczność i powtarzalność motywu to techniki malarskie typowe także dla street artu - formy wykorzystywanej najczęściej przez jednostki społecznie zaangażowane, które chcą zwrócić uwagę przypadkowej, masowej publiczności na aktualne, a ignorowane problemy; jednym $\mathrm{z}$ takich artystów jest np. Brytyjczyk Banksy. Szablon w street arcie wykorzystywany był też w Polsce, np. podczas walki politycznej w czasie niemieckiej okupacji (szablonowa „kotwica”, czyli znak Polski Walczącej), oraz przez Pomarańczową Alternatywę - antykomunistyczny, artystyczny ruch happeningowy.

${ }^{31}$ S. Wysłouch, op. cit., s. 181. 

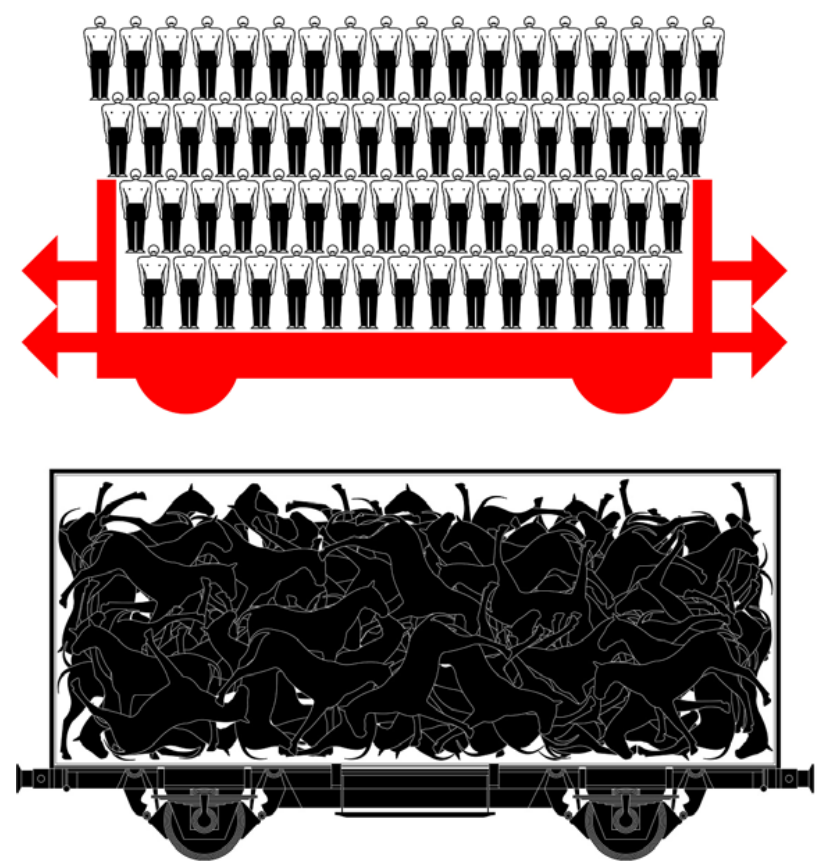

Il. 6-7. Lokomotywa/IDEOLO, fragmenty: „Atleci” i „Konie”, il. M. Gurowska

Ilustracjom w Lokomotywie/IDEOLO nie towarzyszy żaden tekst, co nie znaczy, że nie ma go w książce. Wystarczy odwrócić leporello, by przekonać się, że na odwrocie każdej zilustrowanej strony jest bądź to krótki, czterowersowy fragment wybranego Tuwimowskiego poematu, bądź akapit prywatnego listu Tuwima, bądź urywek z udzielonego przez niego wywiadu, np. w krakowskim „Czasie” w 1935 roku: „Nie jestem poetą par excellence społecznym - stosunek mój do spraw społecznych wyraża się raczej w satyrach i tam ów krytyk przyszłości znajdzie bogate pole do obserwacji, w jaki sposób wpływają na mnie codzienne zdarzenia"32. Zapiskom i refleksjom poety sprzed lat towarzyszą aktualne zestawienia statystyczne dotyczące eksploatacji środowiska naturalnego, hodowli zwierząt i in., wraz z podaniem źródła, np.:

${ }^{32}$ M. Gurowska, J. Ruszczyk, op. cit., s. 5. 
Śmiertelne upadki zwierząt w czasie transportu stwierdzono w 70\% skontrolowanych jednostek. $40 \%$ skontrolowanych firm nie zapewniło zwierzętom warunków bezpiecznego - tj. przede wszystkim niegrożącego urazami i okaleczeniem - przewozu. W poszczególnych transportach przekroczenie norm ładunkowych sięgało od kilku do 95\%. Nadmierne zagęszczenie powodowało nawet zaduszenie zwierząt w czasie transportu. - Raport Najwyższej Izby Kontroli o transporcie koni z 1997 r.

lub:

[...] światowe prognozy na 2015 rok przewidują wzrost zachorowań na otyłość do około 700 milionów osób, liczba osób z nadwagą wzrośnie do dwóch miliardów i sześciuset tysięcy [...] W 1961 roku dzienna liczba kalorii dostarczana z pożywieniem na dobę wynosiła $2300 \mathrm{kcal}$. W 1998 roku wzrosła do $2800 \mathrm{kcal}$. Szacuje się, że w 2015 roku przekroczy $3000 \mathrm{kcal}$. Co roku, na potrzeby konsumenckie, zabijanych jest 56 miliardów zwierząt. Liczba ta nie uwzględnia zwierząt morskich - FAO/Organizacja Narodów Zjednoczonych ds Wyżywienia i Rolnictwa ${ }^{33}$.

W opisie projektu Fundacji Sztucznej czytamy:

Lokomotywa/IDEOLO to odsłona Tuwima zaangażowanego, odważnego, bezkompromisowego w poruszaniu tak trudnych tematów, jak tożsamość narodowa, rasizm, antysemityzm. To Tuwim wciąż aktualny, wręcz gorący, którego teksty poetyckie, satyryczne, listy, wypowiedzi - zestawione z aktualnymi faktami dotyczącymi dzisiejszych kwestii społecznych i politycznych - nabierają jeszcze większej mocy. Sprawdzają się, działają po wielu latach. Na kanwie Lokomotywy powstała książka o współczesnych problemach ekonomicznych, ekologicznych, etycznych... W pociągu jadą Żydzi, kibole, żołnierze, geje i lesbijki, hipsterzy oraz zwierzęta, przewożone są różne materiały ${ }^{34}$.

\section{KONTROWERSYJNE PRAWO CYTATU}

Wiersz Lokomotywa pojawia się w tej książce tylko raz - na wyklejce. Inne cytaty, wykorzystane w IDEOLO i podpisane „Julian Tuwim”, w dużej mierze

33 Ibidem, s. 5-6.

34 Ibidem. 
pochodzą z publicznych wypowiedzi poety, a nie z jego działalności twórczej. Można więc uznać, że Gurowska i Ruszczyk stworzyły, na zasadzie intertekstualnego dialogu, zupełnie nową znaczeniowo Lokomotywę, a ta Tuwimowska jest tylko inspiracją, „zaczynem”, dozwolone jest więc potraktowanie jej na zasadzie dozwolonego przez prawo autorskie cytatu. Mimo to autorki poprosiły Fundację Juliana Tuwima i Ireny Tuwim o licencję. Dlaczego? W przypadku takich inicjatyw jak Lokomotywa/IDEOLO Ustawa o prawie autorskim i prawach pokrewnych pozostawia wiele wątpliwości. W ramach „cytatu” pozwala na wykorzystanie „urywków” rozpowszechnionych utworów ${ }^{35}$. Art. 271 pr. aut., który odnosi się do umieszczania utworów w podręcznikach, antologiach i wypisach, mówi o możliwości wykorzystania całych drobnych utworów bądź „fragmentów” większych. Należy jednak przyjąć, że nie definicja semantyczna pojęcia użytego w art. 29 pr. aut., ale cel dokonanego cytatu będzie przesądzający dla określenia jego dozwolonego rozmiaru, a ocena zakresu dozwolonego cytatu powinna być dokonywana indywidualnie. Wskazuje na to między innymi Elżbieta Traple: „[...] każdorazowe wykorzystanie utworu należy oceniać jedynie indywidualnie, w odniesieniu do konkretnego wypadku. Nie jest możliwe posłużenie się generalnymi kryteriami ilościowymi, wyrażającymi dopuszczalny procent cytatu w stosunku do reszty dzieła, z którego pochodzi, i w odniesieniu do dzieła posługującego się cytatem" ${ }^{36}$. Z taką interpretacją zgodził się Sąd Najwyższy. W wyroku z 23 listopada 2004 roku (I CK 232/04, OSNC 2005/11, poz. 195) wskazał, że „ze względu na różnorodność stanów faktycznych nie jest możliwe stworzenie ogólnej reguły, określającej proporcje utworu przejmowanego do utworu własnego, w każdym razie jednak, jak przyjmuje się w literaturze przedmiotu, cytat w stosunku do całości musi pełnić rolę podrzędną".

Można się upierać, że Lokomotywa Tuwima pełni taką właśnie rolę w stosunku do całości książki Lokomotywa/IDEOLO - podrzędną. Na odwrocie ilustracji pojawia się jednak sporo drobnych fragmentów $z$ innych utworów Tuwima. Pozostają one w dialogu z urzędniczymi danymi ze współczesnego

${ }^{35}$ Ustawa $\mathrm{z}$ dnia 4 lutego $1994 \mathrm{r}$. o prawie autorskim i prawach pokrewnych, op. cit.

36 E. Traple, Dozwolony użytek chronionych utworów, [w:] Prawo autorskie i prawa pokrewne. Komentarz, red. J. Barta et al., Warszawa 2011, s. 271. 
świata oraz z ilustracjami wagonów. Trudno byłoby policzyć i wskazać, jak duża jest tu skala wykorzystania twórczości poety. Utwór ten przypomina zmiksowaną kompozycję twórczego DJ-a. I do takich dzieł odnosił się Sąd Najwyższy w kontekście prawa autorskiego i prawa do cytatu: w wyroku z 5 marca 2002 roku (sygn. akt II KKN 341/99) stwierdził, że praca DJ-a polega na „wyborze, zestawieniu i zespoleniu w jedną całość kilku dzieł lub ich fragmentów, przy równoczesnym dokonaniu pewnych zmian w rytmice, tempie bądź stopniu melodyjności utworów [...] może dochodzić do przesunięcia akcentów w aranżacji utworu z partii jednego instrumentu na inny, zmiany tempa lub powtórzenia określonych tematów muzycznych". Co ważne, SN zakwalifikował DJ-a jako „twórcę utworu zależnego”, któremu należy się ochrona w ramach prawa autorskiego, ale który też - co bardzo istotne - musi ubiegać się o pozwolenia na wykorzystywanie w swojej twórczości dzieł innych twórców, ponieważ tworzy „wiązanki utworów”37. Jak stwierdza Leszek Małek:

Należy zatem zastanowić się, jak należy interpretować cele, które ustawodawca stawia przed cytującym, i w jakim stopniu pozwalają one wykorzystywać cudzy dorobek twórczy przy zastosowaniu przepisu art. 29 ust. 1 pr. aur. W opracowaniach doktrynalnych w odniesieniu do cytatu często używa się zamiennie terminów „cel” i „funkcja”. Trzeba przy tym stwierdzić, że w świetle obecnego stanu prawnego żądne z tych pojęć nie uzyskało statusu normatywnego ${ }^{38}$.

Swoje rozważania badacz konkluduje wnioskiem, iż usprawiedliwianie cytatu respektowanymi przez prawo autorskie „prawami gatunku twórczości” nie jest zgodne z rozwiązaniami przyjętymi w świetle prawa wspólnotowego:

Jak można przypuszczać, masowy rozwój wykorzystywania cudzej twórczości, zwłaszcza w związku z rozwojem nowych technologii, będzie się

37 A. Sewerynik, Prawo autorskie:Didżej-twórca czyodtwórca?, „Rzeczpospolita. Rzecz o Prawie”, 1 października 2016; https://www.rp.pl/Rzecz-o-prawie/310019993 -Prawo-autorskie-Didzej--tworca-czy-odtworca.html [dostęp: 10.08. 2019].

38 L. Małek Ustawowe cele prawa cytatu, „Zeszyty Naukowe Uniwersytetu Jagiellońskiego. Prace z Prawa Własności Intelektualnej” 2008, z. 2, s. 93. 
pogłębiał. To zaś może wywoływać kolejne konflikty wokół posługiwania się instytucją prawa cytatu. Zwraca więc uwagę fakt, że obecny kształt art. 29 ust. 1 pr. aut. otwiera zbyt szeroko furtkę do korzystania z przedmiotów chronionych przez prawo autorskie ${ }^{39}$.

Dociekanie istoty instytucji prawa cytatu w niniejszym artykule jest istotne, można bowiem przypuszczać, iż wiele dzieł nawiązujących do twórczości Tuwima nie powstało lub nie może powstać, ponieważ na sposób wykorzystania danego utworu zgodę musi wyrazić właściciel autorskich praw majątkowych. Problem z jej uzyskaniem wcale nie musi dotyczyć tylko spraw finansowych. We wrześniu 2018 roku media donosiły o odwołanej premierze muzycznego widowiska Tuwim i..., przygotowywanego przez wiele miesięcy w Teatrze Banialuka w Bielsku-Białej. W przygotowania zaangażowani byli mieszkańcy miasta - przekazali autorom scenografii kilkaset małych laleczek, z których powstała ogromna twarz Tuwima w kapeluszu. $\mathrm{Na}$ tym tle wystawiane miały być wiersze, m.in. Okulary, Ptasie radio, Zosia Samosia i Lokomotywa. Mimo iż teatr działał na podstawie licencji i swoje poczynania konsultował z Fundacją im. Juliana Tuwima i Ireny Tuwim, to w ostatniej chwili, jak donosi „Gazeta Wyborcza” z 18 września 2018 roku $^{40}$, Ewa Tuwim-Woźniak, po obejrzeniu przygotowanych materiałów scenograficznych, cofnęła zgodę. Jak pisała w liście uzasadniającym swą decyzję:

Obejrzenie tych materiałów upewniło mnie, że na „wielkie emocje”, których wzbudzenie, jak podano w opisie przysłanym przez Teatr, było jednym z celów autorów przedstawienia, składać się będzie głównie, szczególnie w wypadku małych dzieci, poczucie zaskoczenia i strachu. Jestem pewna, że Julian Tuwim sprzeciwiłby się takiej interpretacji zawartości swoich wierszy dla dzieci. Jego poezja dla dzieci to nie tylko pierwsza, dostosowana do ich wrażliwości wersja opowiadania o świecie, podana przez kochającego je dorosłego i dojrzałego człowieka, ale też opis świata widzianego oczyma szczęśliwego i kochanego dziecka. Zmiany sensu, czy jak to Teatr nazywa,

\section{Ibidem, s. 115.}

40 E. Furtak, Córka Tuwima: „Jestem pewna, że Julian Tuwim sprzeciwitby się takiej interpretacji zawartości swoich wierszy dla dzieci”, „Gazeta Wyborcza”, wydanie lokalne: Bielsko-Biała, 18 września 2018; http://bielskobiala.wyborcza.pl/bielskobia la/7,88025,23937264,corka-tuwima-jestem-pewna-ze-julian-tuwim-sprzeciwilby -sie.html [dostęp: 10.08.2019]. 
nowego odczytywania utworów, trzeba dokonywać ostrożnie, tak, żeby nie przekroczyć granicy, gdzie ta nowa interpretacja bez wiedzy odbiorcy odbiera pierwotnym utworom ich zamierzony sens ${ }^{41}$.

Ostatecznie premierę przesunięto i spektakl pokazano, ale dla publiczności powyżej piętnastego roku życia - zgodnie z życzeniem Tuwim-Woźniak ${ }^{42}$.

Lokomotywa/IDEOLO, zgodnie z umową licencyjną, mogła się co prawda w swej zaangażowanej społecznie postaci ukazać, ale w niewielkiej liczbie egzemplarzy. Nakład pierwszego wydania z 2013 roku wynosił pięćset sztuk, drugiego, polsko-angielskiego, z roku 2015 - tysiąc sztuk. Autorki chciały zrealizować też projekt w wersji francuskiej, ale jak dotąd nie uzyskały na to zgody. IDEOLO wzbudza u licencjodawców podobne wątpliwości, co spektakl Tuwim i... - nie tak powinno się interpretować wiersze dla dzieci.

Tymczasem interpretacja poezji (zwłaszcza poezji) może być każdorazowo, w zależności od odbiorcy, inna. W przypadku Lokomotywy Tuwima od dziesiątek lat podkreśla się, że może być wierszem zarówno dla dorosłych, jak i dla dzieci. Jak pisał Jarosław Mikołajewski, który jest zdania, że Lokomotywa to wiersz dla „ekstremalnie dorosłych”, niemogących nadążyć za zmieniającym się światem i umykającym życiem:

Spróbujmy to zrozumieć od strony życia, a nie tylko dźwięku, który narzuca się przy „dziecinnym” jedynie odczytaniu tego wiersza. Otóż istnieją - i to nie tylko na antypodach naszego świata - ludzie, których fascynuje lub wzrusza rzeczywistość widziana. Dramat ich polega na tym, że w porównaniu z tą fascynującą rzeczywistością czują się oni (i są) względnie niezmienni, podczas gdy ona jest w ruchu. My zostajemy, ktoś odjeżdża - stary i banalny dramat... Weźmy ten konkretny przypadek - człowieka, który patrzy na pociąg. Kiedy lokomotywa stoi na stacji, człowiek i maszyna są wpatrzone w siebie jak powiedzmy - morze i niebo. $Z$ tym że sposób, w jaki niebo odbija morze, znany nie jest, a po morzu można rozpoznać wrażenia $z$ nieba. No więc człowiek jest morzem, lokomotywa jest tajemnicą nieba. I nagle lokomotywa rusza, człowiek na dworcu nie chce się z nią rozstać, więc podczepia się pod jej rytm. Nie mówi już kadencją miarowego oddechu, mówi szaleństwem stukotu rozpędzonej maszyny. Na początku biegnie za nią, lecz nie wystarcza mu sił, żeby krokiem dotrzymać jej pędu. Jest jak morze, które unosi swoje

41 Ibidem.

42 Ibidem. 
fale ku niebu w chwili, kiedy niebo się chmurzy. Pociąg pędzi, człowiekowi wyrywa się serce, jedyna szansa na miłość z pociągiem to poddanie języka jego mowie. Człowiek, który przejmuje mowę lokomotywy, jest jak morze, które przyjmuje na fale swoją porcję nieba w postaci deszczu, który opada z chmur... Tak, tak - Lokomotywa to wiersz o naszej nieruchomej miłości do rzeczy, która jest szybsza od nas. To wiersz dla ekstremalnie dorosłych, który - na szczęście - podoba się dzieciom... ${ }^{43}$

Czy - nazwijmy to - „cenzura” (choć jest to zdecydowanie za mocne słowo) właściciela majątkowych praw autorskich do spuścizny Tuwima oznacza, że np. Lokomotywa/IDEOLO nie będzie wznawiania ani przekładana na inne języki? Niekoniecznie. Autorskie prawa majątkowe są ograniczone w czasie, wygasają siedemdziesiąt lat po śmierci twórcy. W przypadku Juliana Tuwima stanie się to w 2023 roku. Powstaje jednak pytanie, czy otrzymamy wówczas równie imponującą liczbą swobodnie, czasem bardzo dalece, korespondujących ze spuścizną poety utworów? Niewykluczone, choć jak widać we wspomnianych przykładach, to ograniczenia są impulsem dla twórczych kreacji pozostających w dialogu z cytowanym dziełem w sposób niezwykle zaskakujący i niestandardowy.

\section{Bibliografia}

Stanisław Balbus, Interdyscyplinarność - intersemiotyczność - komparatystyka, [w:] Intersemiotyczność. Literatura wobec innych sztuk (i odwrotnie), red. S. Balbus, A. Hejmej, J. Niedźwiedź, TAiWPN Universitas, Kraków [cop. 2004].

Ewa Furtak, Córka Tuwima: „Jestem pewna, że Julian Tuwim sprzeciwiłby się takiej interpretacji zawartości swoich wierszy dla dzieci”, „Gazeta Wyborcza”, wydanie lokalne: Bielsko-Biała”, 18 września 2018; http://bielskobiala.wy borcza.pl/bielskobiala/7,88025,23937264,corka-tuwima-jestem-pewna-ze -julian-tuwim-sprzeciwilby-sie.html.

Dominik Grabowski, Dlaczego?, „Poezja i Dziecko” 2004, nr 4.

Małgorzata Gurowska, Joanna Ruszczyk, Lokomotywa/IDEOLO, wyb. J. Ruszczyk, Fundacja Sztuczna Wytwórnia-Instytut Książki, Warszawa - Kraków 2013.

${ }^{43}$ J. Mikołajewski, op. cit. 
Alicja Helman, Twórcza zdrada. Filmowe adaptacje literatury, Ars Nova, Poznań 1998.

Maryla Hopfinger, Adaptacje filmowe utworów literackich. Problemy teorii i interpretacji, Zakład Narodowy im. Ossolińskich-Polska Akademia Nauk, Wrocław 1974.

Łukasz Kaczyński, Rok Tuwima 2013 w Łodzi, czyli połowa roku gruszek na wierzbie, „Dziennik Łódzki”, 4 stycznia 2014; https://dzienniklodzki. pl/rok-tuwima-2013-w-lodzi-czyli-polowa-roku-gruszek-na-wierzbie/ ar/1080788.

Janusz Lalewicz, Mimetyzm formalny i problem naśladowania w komunikacji literackiej, [w:] Tekst i fabuła, red. C. Niedzielski, J. Sławiński, Zakład Narodowy im. Ossolińskich - Polska Akademia Nauk, Wrocław 1979.

Zbigniew Lisowski, Próba interpretacji „Lokomotywy” Juliana Tuwima, „Zeszyty Naukowe WSR-P im. G. Dymitrowa w Siedlcach" 1988, nr 15, cz. 2.

Leszek Małek, Ustawowe cele prawa cytatu, „Zeszyty Naukowe Uniwersytetu Jagiellońskiego. Prace z Prawa Własności Intelektualnej” 2008, z. 2.

Jarosław Mikołajewski, Lokomotywa i inne wesołe wierszyki, Tuwim, Julian, „Gazeta Wyborcza", 22 listopada 2003; http://wyborcza.pl/1,75517,1786015.html.

Aleksandra Sewerynik, Prawo autorskie: Didżej - twórca czy odtwórca?, „Rzeczpospolita. Rzecz o Prawie”, 1 października 2016; https://www.rp.pl/ Rzecz-o-prawie/310019993-Prawo-autorskie-Didzej--tworca-czy-odtworca. html.

Ewa Szczęsna, Wprowadzenie do poetyki intersemiotycznej, [w:] Intersemiotyczność. Literatura wobec innych sztuk (i odwrotnie), red. S. Balbus, A. Hejmej, J. Niedźwiedź, TAiWPN Universitas, Kraków [cop. 2004].

Elżbieta Traple, Dozwolony użytek chronionych utworów, [w:] Prawo autorskie i prawa pokrewne. Komentarz, red. J. Barta et al., Lex a Wolters Kluwer business, Warszawa 2011.

Seweryna Wysłouch, "Lokomotywa” Tuwima $w$ książce $i$ na ekranie, [w:] Literatura w kręgu sztuki. Tematy - konteksty - medialne transformacje, red. B. Przymuszała, S. Wysłouch, Wydawnictwo Poznańskiego Towarzystwa Przyjaciół Nauk, Poznań 2016.

\section{Źródła internetowe}

http://bip.instytutksiazki.pl/attachments/article/87/Sprawozdanie_2013.pdf. http://www.filmpolski.pl/fp/index.php?film=428064. 
http://www.tuwim.org/index.php?p=4.

https://instytutksiazki.pl/aktualnosci,2,rok-tuwima,1713.html.

https://www.cda.pl/video/469633a.

https://www.cda.pl/video/5383938d.

https://www.youtube.com/watch?v=IgGQYyethAQ.

https://www.youtube.com/watch?v=NLT_Yx5yhGo.

\section{Akty prawne}

Ustawa z dnia 4 lutego 1994 r. o prawie autorskim i prawach pokrewnych; http:// prawo.sejm.gov.pl/isap.nsf/DocDetails.xsp?id=WDU19940240083.

\section{Locomotive on a New Tracks, or How Tuwim is Modernized}

The aim of this paper is an attempt to understand the provenance of various contemporary adaptations and interpretations of the poem Locomotive by Julian Tuwim. Selected and discussed examples of literary works based on Tuwim's Locomotive deviate so much from the original that they are considered not in terms of adaptation or intersemiotic translation, but as inspiration, artistic creation and reinterpretation. One of the reasons for this approach to Tuwim's legacy is the use of right to quote for artistic purposes guaranteed by Polish copyright law, which makes it possible to refer to someone's work without an obligation to ask for authors' or their inheritors' permission. The article also briefly recalls the history of the poem Locomotive and basic interpretations of its original form.

Keywords: Julian Tuwim, Locomotive, Year of Tuwim, adaptation, interpretation, copyright, quotation right 